\title{
Jewel of the East
}

\author{
Colin Renfrew
}

THE great early civilization of the Indian sub-continent remained unknown until the year 1921, when Sir John Marshall made his remarkable - and quite unexpected discoveries at Mohenjo Daro in the Indus Valley and at Harappa. With the recognition of Marshall's finds, knowledge of urban life in the area was taken back two thousand years before the days of Alexander the Great. At a stroke the Indus Valley, in what is today Pakistan and north-west India, was transformed in the eyes of scholars from something of a cultural backwater to one of the world's early heartlands of civilization.

Succeeding generations of scholars have done much to increase our knowledge, not only of the two great cities themselves, but of smaller towns such as Kalibangan in India and the coastal site of Lothal. The heyday of the Harappan civilization, around $2000 \mathrm{BC}$, is now very well documented: large areas of the cities have been cleared, and many aspects of urban life - notably the town planning reflected in the rectangular grid layout, and the very competent drainage systems - seem in advance of their contemporaries in Egypt or Mesopotamia. Only very recently, however, has the previous and formative period of the civilization been intensively studied. And only with the new data uncovered has it become possible to call into question the widespread assumption that the Harappan civilization was some sort of offshoot of Mesopotamian urbanism, a secondary phenomenon whose urban nature was largely due to outside influence.

New excavation at a number of sites, most notably Mehrgarh, has now taken the story very much further back, so that it is now possible to document settled farming life in the area before $5000 \mathrm{BC}$. And at Rahman Deri, the direct antecedents of the Harappan town there are taken back into the fourth millennium $\mathrm{BC}$. The time is therefore ripe for a new work of synthesis to replace the earlier reviews of the civilization, amongst them Bridget and Raymond Allchin's The Birth of Indian Civilisation (Cambridge University Press, 1968).

With The Rise of Civilization in India and Pakistan, the Allchins bring their many years' experience of archaeology of those countries to bear on the wide range of material now available, from Afghanistan and Iran as well as the sub-continent itself. They offer an authoritative and welljudged survey which is likely to stand for many years as the most balanced treatment of this complicated subject.
The Rise of Civilization in India and Pakistan. By Bridget and Raymond Allchin. Pp.379. Hbk ISBN 0-521-24244-4; pbk ISBN 0-521-28550-X. (Cambridge University Press: 1982.) Hbk $£ 25, \$ 49.50$; pbk $£ 8.95, \$ 14.95$.

The authors begin with a thorough review of the prehistoric environments of the region, followed by two chapters which summarize the evidence from the Old Stone Age, and for hunter-gatherers and nomad pastoralists. The new evidence from the French excavations at Mehrgarh comes to the fore in the chapter on the first agricultural communities, and here the authors state their "belief that the indigenous developments of this region are of central significance for the subsequent development of Indian civilization in its widest sense". This view is substantiated in the following chapter on the Early Indus period, where several elements of continuity may be traced, from the preceding Neolithic through into the mature Indus civilization. To say this is not, however, to discount the effects of trade on the growth of early urbanism; relations between the Indus and Afghanistan and the Iranian plateau are now very well documented.

In succeeding chapters the authors deal with the collapse and aftermath of the Indus civilization, taking a properly cautious view about the supposed effects of hypothetical Indo-Aryan invaders at this time. In my own view there are arguments in favour of setting the advent of IndoEuropean speakers very much earlier. The supposed identification of a Dravidian (and therefore non-Indo-European) language in the Indus inscriptions rests more on supposition than on convincing argument.

During the succeeding Iron Age the Ganges seems to replace the Indus as the home of the more dynamic cultural developments. It seems paradoxical that we now understand rather more about the processes favouring the rise of the earlier Indus civilization than we do of that of classical India two millennia later.

The story is clearly told, with a systematic presentation of the archaeological evidence upon which it is based, and with a sound recognition of the limitations and gaps in that evidence. It was, presumably, an editorial decision to avoid all footnotes and text references, and to include only a "select general bibliography" at the back of the book, where further reading is suggested on a chapter- by-chapter basis. This system certainly avoids disrupting the flow of the text, but scholars would certainly have preferred a more detailed reference system. The documentation of radiocarbon dates likewise seems too sketchy for systematic use. The authors' chronological judgement seems entirely sound, but even if individual dates are now too numerous to be listed in their entirety - which I doubt - it might have been possible to represent them all in one or more text figures, which would have illustrated the arguments more fully. The chronology, although doubtless secure in outline, is not yet fixed with any great precision, and the serious reader will wish to see more clearly the evidence upon which it is based.

These criticisms are worth making because The Rise of Civilization in India and Pakistan will justly acquire the status of a standard work: it is certainly the best treatment which we now have of the entire prehistory of the sub-continent. And it will surely stand for many years as the most convenient and reliable introduction, at a serious level, to this fascinating subject. ㄴ?

Colin Renfrew is Disney Professor of Archaeology at the University of Cambridge.

\section{A ball of Cinderellas}

\section{M.J. Wells}

Electrical Conduction and Behaviour in 'Simple' Invertebrates. Edited by G.A.B. Shelton. Pp.567. ISBN 0-19-857171-2. (Oxford University Press: 1982.) f40, \$98.

SCIENCE proceeds by a system of mutual backscratching. The "successful" neurophysiological preparations are those that attract sufficient disciples to form a caucus who will recommend further grants for further research in areas of mutual interest - Aplysia, locusts, squid giant fibres and a few other oddments from arthropods and molluscs, plus, of course, the obligatory rats and cats. Fair enough. It works. Having in effect agreed to limit the field to a few preparations, people at least talk the same language and that encourages them to speak to one another.

But in the long run lodes are worked out and real prospectors are needed, scouting around in unfashionable areas on the offchance of the gold that will unleash another Klondyke. The odd thing about the authors of this collection of papers which specifically avoids both vertebrates and the 